\title{
Antihumanism in queer theory
}

Article

Accepted Version

Zanghellini, A. (2020) Antihumanism in queer theory. Sexualities, 23 (4). pp. 530-548. ISSN 13634607 doi: https://doi.org/10.1177/1363460719842134 Available at https://centaur.reading.ac.uk/82760/

It is advisable to refer to the publisher's version if you intend to cite from the work. See Guidance on citing.

To link to this article DOI: http://dx.doi.org/10.1177/1363460719842134

Publisher: Sage

All outputs in CentAUR are protected by Intellectual Property Rights law, including copyright law. Copyright and IPR is retained by the creators or other copyright holders. Terms and conditions for use of this material are defined in the End User Agreement.

\section{www.reading.ac.uk/centaur}

\section{CentAUR}

Central Archive at the University of Reading

Reading's research outputs online 


\title{
Antihumanism in queer theory
}

\author{
Aleardo Zanghellini
}

\section{Introduction}

Queer theory is a broad church. Some of it - particularly in my own discipline, law - has been described as uninteresting (Leckey and Brooks, 2010: 4). ${ }^{1}$ This is perhaps because, like other post-modern legal academics, queer legal scholars are not generally antimodernist (Feldman, 2001: 2373-2378), and they explicitly enlist deconstruction for prescriptive, rather than relentlessly critical, ends (Balkin, 2005). This reflects the fact that normative questions about what we should do are ineradicable from law (Radin and Michelman, 1991: 1024-1027; Rubin, 1988: 1847-1855). Because, as I will suggest, humanistic concepts and principles remain, for better or for worse, inescapable standards for normatively-oriented thought, law's normative orientation makes it all but inevitable that queer legal theory's relationship to humanism is more often one of ambivalence, rather than outright rejection.

I maintain that such ambivalence - whether expressed in queer legal theory or in other departments of queer theory - is not necessarily less interesting, let alone less legitimate, than outright rejection of humanism. Indeed, the reverse may be true. I will argue that the shortcomings of some queer work are a function precisely of how dead serious it is in its antihumanism. I will illustrate this through an inter-textual analysis of Edelman's (2004) socalled 'antisocial' queer theory, and two seminal queer theory essays by Bersani (1987, 1994). At the same time, I will consider some more recent critical interventions that have impugned queer theory's commitment to antinormativity, arguing that the (main) problem with queer theory is less antinormativity than antihumanism. 
One might ask how useful it is to shift the emphasis away from queer studies' more recent concern with (anti)normativity and return it, via Edelman and Bersani, back on (anti)humanism. But the (anti)humanism question is never far behind the (anti)normativity question. After all, normativities presuppose commitments to understandings of the good, and these understandings in turn presuppose conceptions of human well-being, human needs, human interests, human capacities etc. In that sense, centring queer (anti)humanism, far from shifting the conversation away from (anti)normativity, throws into relief exactly what is at stake when queer (anti)normativity takes the form of a lack of commitment to the good. Because Edelman's brand of 'decidedly anti-humanist' (Giffney, 2016: 73) queer thought embodies the most fully worked out statement of queer antinormativity thus understood, returning to it illuminates much of what silently drives and shapes the current debate on antinormativity.

It could be objected that I am wrong in claiming that normativities presuppose commitments to understandings of human well-being, human needs, human interests, human capacities etc. Are these not now superseded by concerns with the posthuman? But there is nothing approaching a queer consensus about the posthuman project that might make a discussion of (anti)humanism obsolete. Some of the "very palpable resistance by many critical race, feminist, and queer thinkers to posthumanism' is grounded in the perception that posthumanism tends to be associated with a move away from critique of existing oppressive and regulatory regimes and towards a (utopian) reenvisioning of social futures (Luciano and Chen, 2015: 194). But some of the resistance to the posthuman project stems from a different concern: 'The very givenness ... of the human ... is something few, even in queer studies ... want to retreat from, let alone discard' (O'Rourke, 2016: xviii). This queer attachment to the human can and should be defended. On the one hand, it is unclear that queer theorists need to 
de-centre such concepts as human dignity and human status in order to effectively respond to posthuman concerns with developing appropriate ethical relations to the non-human or morethan-human (see for example Sharpe, 2010: 141-142). On the other hand, queer theorists may worry (I do) that the affective appeal of posthumanism, grounded in its bespeaking 'cosmic community', masks both analytical and ethical pitfalls (Porpora, 2017). It seems telling that posthumanism, being worked out from within the very humanist tradition (Badmington, 2003), is inescapably haunted by it, so that decentring the human almost invariably re-centres it: posthuman, non/human (Hird and Giffney, 2016), more-than-human (Alaimo, 2008). ${ }^{2}$ In any case, although space forces me to bracket the question of posthumanism henceforward, it is significant that the kind of queer antihumanism I target has the potential for undermining and hence, potentially, concerns - much posthumanist thought, too. This is because the latter is normatively invested in the good (even if re-conceived along posthumanist lines), and the queer antihumanism I critique in this paper reduces the good and all normative projects (hence, by implication, also posthumanist ones) to contests of power.

My analysis in this essay hopefully will vindicate my belief that the disciplinary perspective from which it proceeds - that of moral/political/legal philosophy - is uniquely placed to illuminate the stakes in queer theory's positioning itself in opposition to humanism. In one sense, my critique is concerned with the performative effects of queer antihumanistic rhetoric: what sort of things do queer words do when queer theory declares itself unconcerned with the good? More concretely, does queer antihumanism assist or occlude our selfunderstanding as practical reasoning agents? Does queer antihumanism map the terrain of the social in ways that assist us in successfully orienting ourselves within it, or does it, rather, leave us drifting, or with the wrong set of coordinates? Centring these questions in my analysis of Edelman (and Bersani's) work means backgrounding an alternative set of questions. Dean (2009), for example, has disputed that Edelman gets his Freud and Lacan 
right, and argued that Edelman's faux pas distort psychoanalysis into 'a dogma' that produces 'the rhetorical effect of authority' (129), and make his political project unviable. LesnikOberstein (2010) has argued that his project is less authentically radical than it claims to be, and less productively queer than it thinks it is. I foreground the question of whether it is a substantively attractive one.

\section{The queer critique of humanism}

Some contemporary social theorists of sexuality adopt unapologetically humanistic approaches and vocabularies (Plummer, 2015). Queer theory, however, is generally taken to be antihumanistic, and especially inimical to liberal humanism and its universalising moves (Halley, 2004: 13, 77, 84, 111, 208; Reddy, 2007/2008; Ruskola, 2005).

In literary studies, where queer theory was pioneered and remains particularly wellembedded, queer antihumanism is continuous with more general (decades-long) disciplinary trends. On the one hand, in the latter half of the twentieth century literary criticism became preoccupied with the Euro-American literary canon's gendered and ethnocentric bias, and started disputing universalist and essentialist assumptions about literature reflecting human experience, teaching universal moral lessons, etc. On the other hand, anti-humanism in literary studies also took the form of a challenge to the autonomous, self-determining human subject, which structuralist and poststructuralist theories saw immersed in a self-referential language and largely at the mercy of linguistic forces that transcend her and rob her of control over meaning (Murdoch, 1992: 185-216).

Queer theory has inherited, contributed to, and radicalised this anti-humanist trend in literary criticism, as well as exported it to other disciplinary domains. In general terms, queer 
theory's antihumanism manifests as a critique of the heteronormative bias in the subject centred by (much traditional) humanism, as well as a critique of humanism-inflected LGBT theories and praxis, which show a tendency to universalise historically and geographically specific sexual and gender identities (Butler, 1997: 12-16; Halley, 2004: 13-14; Jagose, 2015: $28),{ }^{3}$ and are overly reliant on the language of rights, deploying it in the service of ultimately heteronormative ends (Bucar and Enke, 2011: 304; Eng, 2010: xi; Ferguson and Hong, 2012; Gotell, 2002: 106; Malinowitz, 2016; McCluskey, 2016: 120; Ruskola, 2005: 244; Stychin, 2004: 967; Sullivan, 2003: 77). Note how this critique of rights logically ties in with the critique of the humanist subject or 'the radical political aspirations of queer studies' subjectless critique' (Eng, Halberstam, and Muñoz, 2005: 10): conceptually, rights presuppose subjects to whom they can be ascribed, and, substantively, the catalogue of human rights we routinely treat as important presupposes self-determining subjects that have some use for the opportunities these rights afford.

When one looks beyond generic and abstract pronouncements, however, queer critiques of humanism - and particularly of rights-centred liberal humanism - turn out to range from rejection to mere ambivalence (Ball, 2002: 457). A number of queer theorists, for example, recognise that LGBT rights need not work in normalizing ways (Franke, 2010: 318, 2012/2013: 46; Gotell, 2002: 110; Stychin, 1995: 49-50, 64-66, 2004: 965, 968). In a sense, queer scholars are sometimes more humanistic than the tradition they critique, whose shortcomings can be understood as a failure to live up to the requirements of humanistic universal justice. This is especially apparent in Valdes' (1995) antisubordination, liberationist, reformist brand of queer theory. But even queer theories that intensively critique liberal universalism end up conceding that the aim is ultimately to make "just "our" contemporary society governed as it is by legal norms that were once exclusive but are now 
striving for real universality' (Reddy, 2007/2008: 2866); or that universalism has an 'important strategic use ... conjuring a reality that does not yet exist' (Butler, 2002: viii).

The failure of much queer theory to live up to its abstract antihumanistic rhetoric may be due to the intuitive cognitive appeal of humanistic principles (universalism) and concepts (the autonomous right-bearing subject), as distinct from their historically contingent and disappointing concretizations. Alternatively, or additionally, it may be due to the fact that these concepts and principles are inherently impervious to successful deconstruction (compare Derrida, 1992). Thus, Radin and Michelman (1991: 1058) argue that the “"humanist" experience of subjectivity - agency - [may be] an historically irreversible, inexpungible, constitutive aspect of our experience of (human) being', so that we cannot but 'think about the good - the better - world and ourselves acting towards it'. Or, in Murdoch's (1992: 153) words: 'We are not, in ordinary life as opposed to philosophy, determinists ... $[T]$ he person ... is not so easily magicked away. Our present moment, our experiences, our flow of consciousness, our indelible moral sense, are not all these essentially linked together and do they not imply the individual?' Doing away with the individual subject familiar to humanism obscures not only the fact that, to paraphrase Nussbaum (1999: 62), the food I eat does not end up in your stomach, but also the way in which the distinct corporeality of each of us subtends our experience of the agentic self as both connected to the world and phenomenologically irreducible to the Other (Merleau-Ponty, 1962).

On this view, queer theories that take seriously methodological individualism and human agency have the edge over other versions of queer theory because agency and the individual are phenomenologically true (validated by individual experience). This is not to say that queer theory should be subsumed under the liberal project, ${ }^{4}$ if only because we should not concede that liberalism has a monopoly over methodological individualism and the concept 
of human agency. It is, however, to say that a sound queer theory will be humanistic in some important sense of the word, often despite itself.

\section{Queer negativity in No Future}

Some forms of queer theory, however, are genuinely antihumanistic. Edelman's (2004) Lacanian polemic argues that queerness and the figure of the Queer embody resistance to the norm of 'reproductive futurity'. According to this norm, it is desirable that society, its norms, and the systems of meaning on which those norms depend continually reproduce themselves in successively new generations. Edelman (2004: 3-4, 11, 21-22, 31, 75, 153-154) particularly takes issue with the figure of the Child (as distinct from any actual children), which he sees as queerness's nemesis. It is in the Child's name that the cycle of reproduction of the social order is undertaken; in the Child's future interests that the interests and freedom of present people are curtailed; and for the Child's benefit that violence is perpetrated against queers, feminists and everyone who is seen as imperilling reproductive futurity.

Edelman (2004: 153-154) also offers a psychoanalytic explanation of why this violence is committed. Violence against queers is an expression of the death drive, to which all humans are subject. Homophobes are in denial about their own thanatoid pulsions, completely displacing the death drive onto queers, whose non-reproductive sexuality and lifestyle make them easily associated with a denial of the affirmation of the value of life. Homophobes then end up acting out their inner conflict through homicidal violence, thus becoming the instruments of the very drive they deny in themselves and associate with queers.

This analysis could be consistent with a humanistic perspective. One could argue, for example, that:

- Human well-being, including the well-being of queers, is objectively important; 
- We need to work towards a social order in which concern for people's well-being is not dependent on their participation in socially normative relational, intimate and sexual scripts;

- Acknowledging that we are all (partly) impelled by the death drive enhances our selfunderstanding;

- The death drive may take benign forms; indeed it can act - in the language of moral philosophy - as a good-making property, including by accounting for the particular kind of hedonic pleasure that sex is $;^{5}$

- The death drive can also take badly destructive forms; and becoming more attuned to its operation may help us move closer to the kind of social order where people may flourish regardless of their participation in socially normative relational, intimate and sexual scripts.

But Edelman is very careful to steer away from any such line of argument. Indeed, he says that he does not intend to recommend a different kind of social order constructed around the good, or a more accurate understanding thereof (Edelman, 2004: 4, 6). It is not that he thinks that notions such as the moral good, justice, etc are invariably misappropriated by some in order to justify oppressing others. Rather, it would appear that he does not believe in the good at all.

In her critique of queer theory's unwitting collusions with neo-liberalism, McCluskey (2016: 127) has targeted queer theory's tendency to upend 'the idea of a moral "good" defined [in feminist and humanistic terms] as understanding and reducing pain, suffering, and subordination in favor of ... not knowing and not caring about pain, suffering, and subordination'. While McCluskey's critique oscillates between indicting queer theory simpliciter and targeting some queer theory, it seems best applicable to queer theory of the kind Edelman practices. Going forward, although my analysis will remain specifically 
focused on the arguments made in No Future, I am going to make 'queer theory of the kind Edelman practices', rather than Edelman himself, the explicit target of my critique. For convenience, I will call this kind of queer theory (QT)e.

I will speak of (QT)e for two reasons. First, it is impossible and futile to establish whether Edelman actually believes in what No Future says. This is a familiar question of authorial intention that comes up whenever interpreting any text, but it presses itself with particular intensity in this case, because of the counterintuitive nature of some of No Future's claims. Ultimately, what matters is what the texts setting out (QT)e convey and do, rather than what is in their author's mind.

The other reason why I will speak of QT(e) is that I want to signal that what I have to say about Edelman's work applies, mutatis mutandis, to the work of other scholars working, or proposing to work, in similar vein. Although few (perhaps no) queer theorists have taken anti-normativity as far as Edelman's genuine anti-humanism, ${ }^{6}$ Edelman's work remains influential. No Future continues to shape and inspire queer analyses more than one decade after its initial publication (see eg Bliss 2015; Deutscher 2017; Giffney, 2016; Schotten 2018). Additionally, I think queer theory lends itself particularly well to hatching work in the manner of Edelman's, and will continue to do so. This is because a fascination with freedom from normative commitment (and everything such commitment presupposes: conceptions of human well-being, interests, capabilities, etc) is nothing new in Western philosophy (Nussbaum, 1994), and queer theory's preoccupation with antinormativity suggests a heightened susceptibility to the drawing power of this 'freedom'. 


\section{Articulating the value of jouissance}

If (QT)e rejects the idea of moral good, it does value something else: jouissance. The meaning of jouissance - which (QT)e associates with queer sex and queerness - is impossible to articulate satisfactorily because jouissance is whatever is left of reality after you strip away, precisely, the layers of meaning created by and constitutive of the social order. (QT)e, which speaks of 'the meaningless eruptions of jouissance' (Edelman, 2004: 75), describes it as 'a movement beyond ... the distinctions of pleasure and pain, a violent passage beyond the bounds of ... meaning, and law'. Jouissance's violence means that it is also always poised on the cusp of destruction, including of those subject to it; it is inseparable from the death drive (Edelman, 2004: 25). (QT)e also describes jouissance using the metaphor of a void: since nothing can be outside the symbolic order - the web of signification that assigns meaning to things in the world and makes them intelligible to us - all that is left when meaning is stripped away from reality is precisely a void, paradoxically filled with jouissance (Edelman, 2004: 22).

(QT)e argues that the social order and the meanings that constitute it are always in the business of denying this void, 'this intransigent jouissance, this death drive' (Edelman, 2004: 27). The social, striving as it does towards a fantasy of meaningfulness that must deny the meaninglessness and negativity of the death drive, as well as the constitution of the social order itself by the drive, must displace this negativity onto queers and violently sacrifice them to the altar of futurity, understood as the reproduction of meaning and the normative standards that depend on it (Edelman, 2004: 28). This is because - in exposing 'sexuality's inevitable coloration by the [death] drive', its 'senseless pulsions', 'its resistance to determinations of meaning', its lack of teleology, and its circular, repetitive movements queerness embodies jouissance (Edelman, 2004: 27). 
In what sense does (QT)e value jouissance and the queerness that 'delights' (Edelman, 2004: 31) in the negativity of the death drive? The value of queerness and jouissance seems, first of all, to be of the epistemic variety: giving in to jouissance promises a temporary point of access into some truth beyond the purported and manufactured truths of the social order, which are based on a denial of the death drive (Edelman, 2004: 17). In particular, once we have dissolved - by giving in to jouissance - the layers of meaning that insist on people's common humanity and universal goods, we are left with the truth of the irreducible particularity of each subject, a particularity that (so we are told) is itself oriented towards jouissance (Edelman, 2004: 5). So the value of jouissance is perhaps that investing in jouissance reveals it - jouissance, the death drive, inevitable violence - as the naked truth of the human condition. This truth is 'a radical challenge to the very value of the social itself' (Edelman, 2004: 6), that is, its system of signification and its arbitrary construction of moral values.

This epistemic value of jouissance is connected to the political value of queerness and jouissance itself. Specifically, by their figuring jouissance and the death drive, queerness and queer sexuality 'portend the undoing of the social order': thus queerness is 'intent on the end, not the ends, of the social' (Edelman, 2004: 28). Understanding why this jouissance-driven undoing of the social at the hands of queerness has political value presupposes some familiarity with Bersani's queer work. Edelman is generally taken to continue Bersani's - as well as Hocquenghem's (Dean, 2006: 827) - legacy. Yet, as I will argue, there are significant differences between Bersani's queer work and Edelman's, bearing out the point that every tradition is also a betrayal of what is handed over (Balkin, 2005: 726, 731-732).

As it happens, it is precisely betrayal, and specifically its ethical potential in Genet's work, that Bersani (1994) considers in 'The Gay Outlaw'. According to Bersani's reading of Genet, 'between oppression now and freedom later there may have to be a radical break with 
the social itself', and betrayal can contribute to bringing about precisely this rupture of the social order (Love, 2009: 257). Betrayal is contiguous with the death drive: like the death drive, it is both a 'will to destroy', and something that gay sex has a special affinity for (Bersani, 1994: 9-11). To his credit, Bersani (1994) avoids committing himself to the implication of Genet's work - namely, that if we only unleash betrayal and its thanatoid will to destroy, in time something better might emerge from the ruins. Indeed, Bersani (1994: 14) is troubled by Genet's 'proclaimed indifference to human life as well as his willingness to betray every tie and every trust between human beings'. Bersani (1994) speaks of Genet's 'intolerable moral logic' (9), of the 'abhorrent' basis of its 'revolutionary strength' (12), of its 'repellent' quality (14) - and he appears to be delivering all these moral judgements using a first person perspective. Finally, Bersani (1994: 18) concludes the essay by making it clear that Genet himself expressly authorizes us to treat his work as nonsense, so that in the end the message to take home from reading Genet is simply, and reassuringly, a generic exhortation 'to rethink what we mean and what we expect from communication, and from community'.

On the other hand, (QT)e - where it recommends embracing jouissance and the death drive - takes itself entirely seriously and demands that we take its arguments quite literally. Its invitation to invest in queerness-as-jouissance-as-the-death-drive seems to actually want to replace a humanistic politics of the moral good with a queer realpolitik of sorts - namely, the kind of 'directly self-interested contest of power that might lead to radical change' that McCluskey (2016: 124) decries in her feminist critique of (some) queer theory.

Furthermore, the radical change facilitated by jouissance which is envisioned by (QT)e differs from that which Bersani gestures towards. In 'Is the Rectum a Grave?', an article predating his analysis of Genet in 'The Gay Outlaw', Bersani (1987) recommended giving in to the jouissance induced by queer sex in order to precipitate the dissolution of the self. But, in so doing, Bersani was inviting us 'to trace new forms of sociability, new ways of 
being together, that are not grounded in imaginary identity or the struggle for intersubjective recognition' (Dean, 2006: 827). Whatever shape these new forms of sociability might take, Bersani's idea was that they would be non-violent, or less violent than current forms of relationality. Specifically, where Bersani (1987: 222) extolled gay sex for its potential for dissolving the self, he had done so on the ground that the self, with its fantasies of mastery, 'is a sanction for violence'. This makes clear that the political vision animating Bersani's investment in (queer) sex and jouissance was ultimately informed by ethical values inherited from the humanistic tradition. ${ }^{7}$

Now contrast Bersani's vision of queer sex as catalysing a world of non-violent relationality with the radical change envisioned by (QT)e, which makes the inescapable violence of the death drive not just a means to an end, but an end in itself. For (QT)e the point is not to replace one system of meaning and norms with a different, more benign one: it is rather to do away with the good, with meaning itself, so as to liberate the drive as far as possible from the social order's attempts at denying it as the real at the heart of the social. That (QT)e might recognize the ultimate futility of this goal does little to negate its commitment to it.

\section{Queer amorality}

McCluskey's (2016) critique of (some) queer theory argues that: a) queer theory takes the 'complexity and fluidity of the harmful and the beneficial in sex to question moral judgments in general good'; b) queer theory treats morality as the effect of contests of power, rather than the 'benchmark by which to measure and correct power imbalances' (125); and c) queer theory adopts an 'inverted moral stance', 'affirming sex as bad' (127). All of these points apply to (QT)e. Yet this gives rise to a paradox. How can (QT)e deny the meaningfulness and 
validity of moral judgements and, at the same time, invest in the moral bad qua bad? How, in other words, can it be simultaneously a case of amorality and immorality?

This apparent contradiction can be resolved if we can interpret (QT)e in a way similar to Bersani's take on Genet's argument that queerness is especially allied to betrayal, and on his perverse suggestion that betraying our friends is just what we, as queers, should do. According to Bersani (1994: 10), even if Genet's invitation is not simply to fail to invest in friendship, but to betray friendship, it does not represent an inversion of values. If it were, it would make it a case of immorality (deliberately choosing the bad because it is bad) not amorality (rejecting the validity of all moral values).

Bersani tells us that Genet is not saying that betrayal must be worshipped as a counter-value. Rather, Genet's writings recommend that we should embrace betrayal as a way of wiping the slate clean, as a way of 'turning away from the entire theatre of the good and its transgressions' (Bersani, 1994: 10). On this reading, Genet's recommendation to betray friendship does not foreground the thrill of doing something morally illicit; rather, it simply signals the rejection of the humanistic principle that people are valuable in themselves: since people's well-being does not matter, we have no reasons to be faithful to them. This quintessentially embodies the amoral stance: for the amoralist 'is not a Miltonian Lucifer knowing the truth and rejecting it in his life... he [simply] does not believe that it has any validity’ (Raz, 1999: 273).

We can read (QT)e's investment in the death drive in the same way as Bersani (1994: 10) reads Genet's investment in betrayal: not, that is, as a case of immoralistic idolatry, but, to repeat, as an amoral 'turning away from the entire theatre of the good and its transgressions'. On this view, (QT)e's far-reaching rejection of values and its emphasis on antirelationality (underpinned as they are by investment in the violence of the death drive) appear to commit (QT)e to denying the principle that people are valuable in themselves. This 
commits QT(e) to amorality in the same way as investment in betrayal commits Genet to amorality. Indeed, QT(e)'s commitment to amorality is more significant than Genet's. For (QT)e encourages us to take its amorality seriously, at face value - thus carrying forward Genet's legacy, but without Genet's own disclaimer about how seriously we should take his professed amorality.

(QT)e's amorality, if taken at face value, is genuinely antihumanistic, for it is characteristic of humanism to subscribe to the principle that people are valuable in themselves. Specifically, in political and moral philosophy, humanism is the particular outlook of a diverse range of perspectives which accept the principle - whether or not they articulate it - that: a) Each human life has value for the kind of thing that it is; and b) Humans are ends in themselves, or at least they are, barring extreme scenarios such as irreversible brain death. ${ }^{8}$ Saying that humans are ends in themselves means that what is of value in the world derives that value from its contribution to human well-being - that is, to human life and its quality (Raz, 1986: 178). The key point is that what is good must, ultimately, always be so for someone (Raz, 1999: 290), and for humanists that 'someone' means humans.

\section{Queer immorality}

To recap: we were grappling with the puzzle of how to make sense of the tension between (QT)e's (amoral) denial of the validity of all moral judgements and its simultaneous (immoral) investment in the moral bad qua bad. I provided one possible answer: (QT)e's investment in the death drive is purely strategic, like Bersani's reading of Genet's (possibly facetious) investment in betrayal. On this reading, both investments are recommended as ways of training ourselves, as it were, to suspend belief - indefinitely - in the validity of moral values. ${ }^{9}$ This reading makes (QT)e's valorisation of the death drive less the expression 
of immorality that it might, at first blush, appear to be, than a stance consistent with its professed amorality.

I think, however, that a more straightforward explanation of (QT)e's simultaneously denying the validity of all moral judgements and investing in the moral bad qua bad is simply that (QT)e is a project internally torn between irreconcilable amoral and immoral tendencies. The reason why (QT)e invests in the death drive is not that the death drive assists (QT)e in turning away from the contest between good and evil. It is not as if (QT)e has come to realise that we must wean ourselves off the idea of the good, and then looked for a way to undermine belief in the validity of moral values, hitting on the death drive (like Genet hit on betrayal) as the best such way. Rather, (QT)e's turning away from good and evil is a consequence of investing in the death drive for its own sake. QT(e)'s discovery of, and infatuation with, the death drive logically precedes, rather than follows, its abandonment of moral values. Its belief in the death drive as the ineradicable truth beyond meaning is the reason why (QT)e ends up concluding that good and evil are sham, fictions set up to deny the death drive.

It is mysterious, however, why the death drive needs to be elevated to the role of allruling organizing principle that (QT)e assigns to it. Freud (1995: 142), for one, recognized that all of us harbour the death drive within us, as well as the ways in which it shapes our outward interactions and our sexual fantasies. None of this, however, meant that the drive had to be treated as an all-ruling epistemic and political value requiring the relativisation of moral goods, the dissolution of the social, and the evacuation of meaning.

The allure of the death drive for (QT)e can be explained by considering the anomic tendencies in (QT)e. Anomia is one kind of immorality. Immorality is conduct guided by disvalues rather than values; not by the good-making properties of certain things, relationships, or courses of action, but by what makes certain actions, things or relationships bad. The other kind of immorality, alongside anomia, is akrasia. People who act for akratic 
reasons know what the right course of action is, but they do not follow it, and they cannot explain why, though they can explain the attraction of the wrong option (Raz, 1999: 35-36).

Akrasia is not the type of immoral stance queer theorists would care for. Akrasia is bit like addiction, rather a pathetic affair. Anomia, on the other hand, is Byronic and sexy. People who act for anomic reasons deliberately choose what they know to be bad, rather than mistakenly believing it to be good, or choosing it, as in the case of akratic reasons, against their better judgement (Raz, 1999: 31-34).

We would not be queer theorists if we were not narcissistically invested in a vision of ourselves as romantic antiheroes. This is one of the reasons that account for some of the deliberate silences and ambiguities in our work: we try to avoid spelling out some assumptions or judgements that align with normative exercises of practical reason, lest we should come across as a little pedestrian, a little too humanistic, a little uncool relative to our impossibly queer academic colleagues. That same übermenschlich self-conception enraptures (QT)e to the point of driving it towards affirming a type of antinormativity that embraces not only the marginal, subordinated, and quaint, but also the bad, the anomic - specifically, the violence of the death drive, both as a means to an end and as an end in itself. For, as we have seen, (QT)e affirms queerness/jouissance/the death drive not only as an epistemic value (jouissance reveals that the violence of jouissance is the ineradicable truth of the human condition) but also as a political one: jouissance is affirmed in the name of, and as a way of returning the world to, the ineradicable truth of jouissance.

In sum, (QT)e trades on the ambiguity between amorality and immorality. In doing so it consigns itself to the paradox of endorsing an amoral stance predicated on an affirmation of anomia. If that were not enough, just as its amorality disables it from offering a serious alternative to the humanistic model of value-driven practical reason, so its anomia fails to seriously challenge that model: for anomia re-affirms the good in the process of negating it. 
This is because anomic reasons are actually non-reasons, and hence provide no sound guide to conduct: they are the wrong kinds of facts to be (true) reasons (Raz, 1999: 33) - reasons being facts about the good-making properties of the world (Raz, 1999: 25).

The appeal of anomic (non-)reasons - the reason why we sometimes take them to be actual reasons - is due to the fact that they are an inversion of true reasons, coupled with the fact that those with anomic tendencies are psychologically drawn to that which runs counter to standard or conventional judgement, whether sound or otherwise (Raz, 1999: 33). If this sounds familiar, it is because, as queer theorists, our default setting is (frequently) on the antinormative. Being drawn to the antinormative is not inherently a bad thing. If it were, that would undermine all of queer theory. But acting on the basis of anomic reasons is a bad thing, detracting as it does from the well-being of the agent and, generally, others.

Surprisingly, (QT)e concedes, in passing, that queers, in addition to investing in queerness, jouissance, and the truth of the death drive, should 'insist on our equal right to the social order's prerogatives' (Edelman, 2004: 29); and adds that 'the liberal discourse and patient negotiations of tolerances and rights' are 'important ... to all of us still denied them' (16). Is it possible to interpret these ideas in line with (QT)e's professed (antihumanistic) amorality/immorality? Perhaps one could make a case that rights, tolerance and social prerogatives increase queers' clout, thereby making queers more effective vectors of the death-drive. This would maintain coherence between (QT)e's amorality/immorality and its concession that rights and tolerance matter. But this interpretation seems strained. Consider (QT)e's terminological choices: rights are invoked not just for queers, but 'for all of us still denied them'; and social prerogatives are sought after as a matter of 'equal right'. Does this not betray typically humanistic concerns? Is it not really an implicit endorsement of something like the principle that humans are ends in themselves? Thus, QT(e) not only 
commits itself to incoherence by being torn between anomic urges and its professed amorality; it also, ultimately, fails to deliver on its promise to reject the good.

\section{Futurelessness is a comparatively lonely place}

Muñoz (2006: 285) has questioned (QT)e's reduction of 'the radical' to 'extremity' or 'affirmation of newness', advocating, against (QT)e, a 'queer utopianism' invested in both 'relationality and futurity'. Nonetheless, the antihumanistic political vision championed by Edelman has some echoes elsewhere in queer theory. For example Halley's (2004: 52-53) endorsement of the view that queer theory is about "affirming sex, "dark side and all" and her acceptance that this 'has very obscure and indeterminate consequences for political affiliation and initiative' resonates with (QT)e. Halley (2004: 21-22) has also taken Bersani to task for ending up celebrating queer sex's jouissance as morally redemptive. Yet, tantalizingly, Halley (2006: 87) elsewhere speaks, approvingly, of 'visionary humanism' though it is uncertain what she means by it.

Even some queer scholarship commonly associated with (QT)e does not, in fact, share (QT)e's antihumanism. Halberstam's work is generally grouped with (QT)e under the banner of antisocial queer theory. But Halberstam - albeit professing to share a politics of negativity with (QT)e - is critical of (QT)e. The ground of Halberstam's (2006: 824) critique is not 'the meaning of [queer] negativity', but (QT)e's failure to develop a politics of negativity in relation to a rich array of queer writings on and engagements with negativity that goes beyond (QT)e's 'gay male archive'. Halberstam (2006: 824) goes on to note that this archive 'is also bound by a particular range of affective responses' (such as 'indifference, ennui', 'insincerity'), and argues that this 'occludes another suite of affectivities associated ... with 
... different form of negativity: ... rage, rudeness, anger, spite, impatience, intensity, mania, sincerity, earnestness, overinvestment, incivility, and brutal honesty'.

Halberstam's critique has bite, but understates how vastly different the project Halberstam is committed to is from (QT)e. Consistent with (QT)e's amorality, the range of affects Halberstam associates with (QT)e are distinctive of the decadent, fin-de-siècle subject experiencing a loss of humanistic values. On the other hand, the alternative range of affects preferred by Halberstam are - in Halberstam's (2008: 149-151) own examples of queer engagements that display them - born of painfully intense investments in such humanistic values as justice, equality, solidarity, and of frustration at their routine violation even by those who ostensibly affirm them. To be sure, Halberstam's (2008: 150) imaginative project is hardly one of progressive, reformist liberal humanism. Nonetheless it is animated by basic humanistic principles, in which human flourishing is not measured by the narrow and bankrupt normative scripts prevalent in deeply inequitable and over-individualistic contemporary capitalist societies (Halberstam, 2011). This humanistic drive makes Halberstam's project - 'reformulating negativity in more affirmative, if not utopian, terms' (Wiegman, 2017: 220) - far removed from (QT)e's queer realpolitik - something Edelman (2006: 822) himself recognizes.

\section{AntiHumanism and antinormativity}

The queer sensibility - one of waywardness, defiance, insubordination, iconoclasm - drives queer theorists' trenchant analyses of the ways in which LGBT liberal humanism and politics can go wrong. It also alerts us to the unwarranted assumptions or exclusionary effects that follow from recommending particular social arrangements in light of unduly narrow conceptions of well-being. This queer sensibility also drives queer theorists to perform - for 
both their own benefit and that of other queer theorists (and, hopefully, to the horror of nonqueers) - their antinormativity in the form of antihumanism. But this performance of antihumanism need not always be taken at face value. All scholarship is a mix of communicative and strategic aims (compare Rubin, 1992: 744-745). I think that queer antihumanism is less about the statement of a philosophically coherent (and hence intelligible) stance, than a strategic device that enables outsider scholars to create a distinctive collective identity, consolidate their outsider status, and establish degrees of political radicalism relative to one another. Perhaps the distinctive critical energy of queer theory is necessarily bound up with its performance of antihumanism, so that giving the latter up may enervate queer critique. If so, however, it is worth remembering that it 'is an exercise in futility to anoint any particular critical stance or political movement with permanent transgressive or revolutionary status' (Rubin, 2010: 369-370).

In objecting to the performance of queer antinormativity that takes the appearance of queer antihumanism, I do not want to indict queer antinormativity in itself. Wiegman and Wilson (2015) have recently argued that queer theory too often fails to recognize the complex and ambivalent nature of the norms it attacks as heteronormative, treating them purely as oppressive, thereby making critical engagements with norms unthinkable, and leaving insubordination to norms as the only authentically queer option. Through a genealogical and conceptual analysis of 'norm', Wiegman and Wilson (2015: 11-15) argue that since the beginning of the $19^{\text {th }}$ century norms have come to reference the idea of 'average' rather than juridical prohibition. Because 'a norm, as a system of averaging, is not invested in singularity', it is 'already generating the conditions of differentiation that antinormativity so urgently seeks' (2015: 16). Queer antinormativity, they argue, misses all this complexity.

I concur with Wiegman and Wilson's conclusion that antinormativity can become disabling: I stated my own version of that argument a decade ago (Zanghellini, 2009). Yet I 
cannot agree with the ground of their critique, for it is unclear to me that the norms targeted by queer theory function like averages, rather than socially ratified prescriptions. Be that as it may, the critique of antinormativity (either Wiegman and Wilson's, or mine) should not lead us to lose sight of the fact that deviation from norms often exacts considerable social penalties, even when they fall short of coercion. ${ }^{10}$ There is much to be said, therefore, for queer theory to continue to default to antinormativity - that is, for it to make it its business to identify, target, discredit and undermine those norms that operate in unjustifiably constraining ways, and which are not generally recognized for what they are.

A critique of existing regimes of normativity has always been central to the queer project (Jagose, 2015: 31), encouraging queer theorists to default to the antinormative (Romero, 2016: 192). An antinormative sensibility is a good thing, so long as its energies end up being concentrated on targeting norms whose existence is not normatively desirable. We target (or leave alone) social and legal norms after judging their justifiability against upper level normative standards. Humanistic standards - contested and liable to refinement as they may be, particularly in light of the experiences of subordinated Others - are the best upper level norms at our disposal for that task, and seem likely to remain so. Much queer theory operates (sometimes despite itself) as if it knows this. That (QT)e is the marginal and antinormative within queer theory's norm demonstrates the ethical inevitability, even for queer theory, of judging not only between good and bad normativities, but also between good and bad antinormativities.

\section{NOTES}

\footnotetext{
${ }^{1}$ An assessment the authors ascribe to Halley and Parker (2011: 3).

${ }^{2}$ Even the most powerful challenges to humanistic thinking - namely, Indigenous epistemologies - may reinstate the centrality of the human in the process of disavowing it. See, eg, Watts (2013), where the human
} 
('Sky Woman') is the centrepiece of creation stories (see eg Watts, 2013); or Arabena (2008: 10), where the primacy of the Universe is conveyed through anthropomorphic imagery ('The (Yanangu) law is like a human being, it works with Aboriginal people').

${ }^{3}$ For some cautionary notes about the political risks of taking the deconstruction of the LGBT subject to its logical extreme, see Moon (2010: 364-365).

${ }^{4}$ Interrogating the relationship between liberalism and queer theory, and their respective aspirations to justice, exceeds the scope of my analysis. I limit myself to noting that although there are undeniable discontinuities on, for example, matters of strategy between a radical queer politics and a liberal politics focused on deliberative processes, there also are affinities between some queer and liberal theories through their commitment to an autonomy-centred understanding of human well-being. Thus, Warner's (1999) explicit rejection of moral relativism $(4-5,43)$, the central place he assigns to personal autonomy $(1,4)$, his willingness to discriminate between valuable and non-valuable options $(5,7)$, and his account of the pre-conditions for the exercise of meaningful autonomy $(7,12,71)$ are both consistent with and illuminated by Raz's $(1986)$ liberal political philosophy. Meanwhile, Warner's (1999) understanding of desire (7) presupposes something like Raz's (1999) humanistic account of intentional conduct (25-45).

${ }^{5}$ Freud (1995) argues that a 'portion of the [death] instinct is placed directly in the service of the sexual function, where it has an important part to play'.

${ }^{6}$ See below, section entitled 'Futurelessness is a comparatively lonely place.'

${ }^{7}$ Humanism does not necessarily reject all violence. Some humanistic theories, for example, recommend revolutionary violence; but even then violence is enlisted, as necessary evil, in the service of bringing about better, non-violent worlds. (See, e.g., Merleau-Ponty, 1969: 106-110.)

${ }^{8}$ My formulation is more or less equivalent to Raz's (1986: 194) 'humanistic principle', according to which anything valuable derives its value from its contribution to human well-being. The only difference is that my formulation leaves open the possibility that for some humanists some non-human life and its quality may also be an end in itself, narrowing the gap between my formulation of humanism and the posthumanist project.

${ }^{9}$ On this reading, Genet's investment in betrayal and (QT)e's investment in the death drive reproduce the moves of the ancient sceptics, who, in a quest to achieve freedom from disturbance (ataraxia), tried to induce in themselves a suspension of normative commitment (epochê), by becoming convinced, 'in any way at all', of the equal force of opposing normative statements (isostheneia). See Nussbaum (1994: 720).

${ }^{10}$ For a more general critique of Wiegman and Wilson's project see Halberstam (2015). 


\section{REFERENCES}

Alaimo S (2008) Trans-Corporeal Feminisms and the Ethical Space of Nature. In: Alaimo S and Hekman S (eds) Material Feminisms. Bloomington: University of Indiana Press.

Arabena K (2008) Indigenous Epistemologies and Wellbeing: Universe Referent Citizenship. AIATSIS Research Paper 22, https://aiatsis.gov.au/sites/default/files/products/ discussion_paper/arabena-dp22-indigenous-epistmology-wellbeing-universe-referentcitizenship_0.pdf (accessed 28 January 2019).

Badmington N (2003) Theorizing Posthumanims. Cultural Critique 53: 10-27.

Balkin JM (2005) Deconstruction's Legal Career. Cardozo Law Review 27: 719-740.

Ball CA (2002) Sexual Ethics and Postmodernism in Gay Rights Philosophy. North Carolina Law Review 80: 371-464.

Bersani L (1987) Is the Rectum a Grave? October 43: 197-222.

Bersani L (1994) The Gay Outlaw. Diacritics 24: 4-18.

Bliss J (2015) Hope against Hope: Queer Negativity, Black Feminist Theorizing, and Reproduction without Futurity. Mosaic 48: 83-98.

Bucar E and Enke A (2011) Unlikely Sex Change Capitals of the World: Trinidad, United States, and Tehran, Iran, as Twin Yardsticks of Homonormative Liberalism. Feminist Studies 37: 301-328.

Butler J (1997) Critically Queer. In: Phelan S (ed) Playing with Fire: Queer Politics, Queer Theories. London and New York: Routledge, pp. 11-29.

Butler J (2002) Gender Trouble, Feminism and the Subversion of Identity: Tenth Anniversary Edition. London and New York: Routledge.

Dean T (2006) The Antisocial Homosexual. PMLA 121: 826-828.

Dean T (2009) An Impossible Embrace: Queerness, Futurity and the Death Drive. In: Bono JJ, Dean T, and Ziarek EP (eds), A Time for the Humanities: Futurity and the Limits of Autonomy. New York: Fordham University Press, pp 122-140.

Derrida J (1992) Force of Law: The "Mystical Foundation of Authority". In: Cornell D, Rosenfeld M, and Carlson D (eds) Deconstruction and the Possibility of Justice. London and New York: Routledge, pp. 3-67. 
Deutscher P (2017) Foucault's Futures: A Critique of Reproductive Reason. New York: Columbia University Press.

Edelman L (2004) No Future: Queer Theory and the Death Drive. Durham, N.C.: Duke University Press.

Edelman L (2006) Antagonism, Negativity, and the Subject of Queer Theory. PMLA 121: 821-823.

Eng DL, Halberstam J, and Muñoz JE (2005) Introduction. Social Text 23: 1-17.

Eng DL (2010) The Feeling of Kinship: Queer Liberalism and the Racialization of Intimacy. Durham, N.C.: Duke University Press.

Feldman SM (2001) An Arrow to the Heart: The Love and Death of Postmodern Legal Scholarship. Vanderbilt Law Review 54: 2351-2378.

Ferguson RA and Hong GK (2012) The Sexual and Racial Contradictions of Neoliberalism. Journal of Homosexuality 59: 1057-1064.

Franke KM (2010) Eve Sedgwick, Civil Rights and Perversion. Harvard Journal of Law \& Gender 33: 313-319.

Franke KM (2012/2013) Dating the State: The Moral Hazards of Winning Gay Rights. Columbia Human Rights Law Review 44: 1-46.

Freud S (1995) The Economic Problem of Masochism. In: Fitzpatrick Hanly MA (ed) Essential Papers on Masochism. New York: New York University Press, pp. 274-285.

Giffney N (2016) 'Queer Apocal(o)ptic/ism: The Death Drive and the Human.’ In Hird MJ and Giffney N (eds) Queering the Non/Human. London and New York: Routldge, 55-78.

Golder B (2010) Foucault and the Unfinished Human of Rights. Law, Culture \& the Humanities 6: 354-374.

Golder B (2013) Foucault, Rights and Freedom. International Journal for the Semiotics of Law 26: 5-21.

Gotell L (2002) Queering Law: Not by Vriend. Canadian Journal of Law \& Society 17: 89113.

Gross AM (2015) The Politics of LGBT Rights in Israel and Beyond: Nationality, Normativity, and Queer Politics. Columbia Human Rights Law Review 46: 81-152.

Halberstam J (2006) The Politics of Negativity in Recent Queer Theory. PMLA 121: 823825.

Halberstam J (2008) The Antisocial Turn in Queer Theory. Graduate Journal of Social Science 5: 140-56. 
Halberstam, J (2011) The Queer Art of Failure. Durham, N.C.: Duke University Press.

Halberstam J (2015) Straight Eye for the Queer Theorist: A Review of 'Queer Theory without Antinormativity'. Available at https://bullybloggers.wordpress.com/2015/09/12/ straight-eye-for-the-queer-theorist-a-review-of-queer-theory-without-antinormativity-byjack-halberstam/ (accessed 25 December 2017).

Halley I (2004) Queer Theory By Men. Duke Journal of Gender Law \& Policy 11: 7-54.

Halley J (2006). Split Decisions: How and Why to Take a Break from Feminism. Princeton: Princeton University Press.

Halley J (2008). Rape in Berlin: Reconsidering the Criminalization of Rape in the International Law of Armed Conflict. Melbourne Journal of International Law 9: 78-124.

Halley J and Parker A (2011) Introduction. In: Halley J and Parker A (eds) After Sex?: On Writing Since Queer Theory. Durham, NC: Duke University Press, pp. 1-16.

Hird MJ and Giffney N (eds) (2016) Queering the Non/Human. London and New York: Routldge.

Jagose A (2015) The Trouble with Antinormativity. Differences 26: 26-47.

Leckey R and Brooks K (2010) Introduction. In: Leckey R and Brooks K (eds) Queer Theory: Law, Culture, Empire. Abingdon: Routledge-Cavendish, pp. 1-18.

Lesnik-Oberstein, K (2010) Childhood, Queer Theory and Feminism. Feminist Theory 11: 309-321.

Love HK (2009) Emotional Rescue. In: Halperin DM and Traub V (eds) Gay Shame. Chicago: University of Chicago Press, pp. 256-276.

Luciano D and Chen MY (2015) GQL 21: 183-207.

Malinowitz H (2016) Liberal Humanist 'Rights' Discourse and Sexual Citizenship. In: Alexander J, and Rhodes J (eds) Sexual Rhetorics: Methods, Identities, Publics. London and New York: Routledge, pp. 224-258.

McCluskey MT (2016) How Queer Theory Makes Neoliberalism Sexy. In: Fineman MA, Jackson JE, and Romero AP (eds) Feminist and Queer Legal Theory: Intimate Encounters, Uncomfortable Conversations. London and New York: Routledge, pp. 115-134.

Merleau-Ponty M (1962) The Phenomenology of Perception. London and New York: Routledge.

Merleau-Ponty M (1969) Humanism and Terror: The Communist Problem. Boston: Beacon Press. 
Moon J (2010) Gay Shame and the Politics of Identity. In: Halperin DM and Traub V (eds) Gay Shame. Chicago: University of Chicago Press, pp. 357-368.

Muñoz JE (2006) Thinking beyond Antirelationality and Antiutopianism in Queer Critique. PMLA 121: 825-826.

Murdoch I (1992) Metaphysics as a Guide to Morals. London: Chatto \& Windus.

Nussbaum MC (1994) Skepticism about Practical Reason in Literature and the Law. Harvard Law Review 107: 714-744.

Nussbaum MC (1999) Sex and Social Justice. Oxford: Oxford University Press.

O'Rourke M (2016) The Open. In: Hird MJ and Giffney N (eds) Queering the Non/Human. London and New York: Routldge, pp. xvii-xxi.

Plummer K (2015) Cosmopolitan Sexualities: Hope and the Humanist Imagination. Cambridge: Polity Press.

Porpora DV (2017) Dehumanization in Theory: Anti-Humanism, Non-Humanism, PostHumanism, and Trans-Humanism. Journal of Critical Realism 16: 353-367.

Radin MJ and Michelman F (1991) Pragmatist and Poststructuralist Critical Legal Practice. University of Pennsylvania Law Review 139: 1019-1058.

Raz J (1986) The Morality of Freedom. Oxford: Oxford University Press.

Raz J (1999) Engaging Reason: On the Theory of Value and Action. Oxford: Oxford University Press.

Reddy C (2007/2008) Time for Rights? Loving, Gay Marriage, and the Limits of Legal Justice. Fordham Law Review 76: 2849-2871.

Romero AP (2016) Methodological Descriptions: 'Feminist' and 'Queer' Legal Theories. In: Fineman MA, Jackson JE, and Romero AP (eds) Feminist and Queer Legal Theory: Intimate Encounters, Uncomfortable Conversations. London and New York: Routledge, pp. 179-198

Rubin EL (1988) The Practice and Discourse of Legal Scholarship. Michigan Law Review 86: 1835-1905.

Rubin EL (1992) What is Prescriptive Legal Scholarship and Who is Listening to It: A Response to Professor Dan Cohen. University of Colorado Law Review 63: 731-750.

Rubin G (2010) A Little Humility. In: Halperin DM and Traub V (eds) Gay Shame. Chicago: University of Chicago Press, pp. 369-373

Ruskola T (2005) Gay Rights versus Queer Theory: What Is Left of Sodomy after Lawrence v. Texas? Social Text 23: 235-249. 
Schotten CH (2018) Queer Terror: Life, Death, and Desire in the Settler Colony. New York: Columbia University Press.

Sharpe AN (2010) Foucault's Monsters and the Challenge of Law. Abingdon: Routledge.

Stychin CF (2004) Same-Sex Sexualities and the Globalization of Human Rights Discourse. McGill Law Journal 49: 951-968.

Stychin CF (1995) Essential Rights and Contested Identities: Sexual Orientation and Equality Rights Jurisprudence in Canada. Canadian Journal of Law \& Jurisprudence 8: 49-66.

Sullivan N (2003) A Critical Introduction to Queer Theory. New York: New York University Press.

Warner M (1999) The Trouble with Normal: Sex, Politics and the Ethics of Queer Life. Cambridge, MA: Harvard University Press.

Watts V (2017) Indigenous Place-Thought \& Agency amongst Humans and Non-Humans (First Woman and Sky Woman go on a European World Tour!) Re-Visiones 7:

http://www.re-visiones.net/index.php/RE-VISIONES/article/view/228/409 (accessed 28 January 2019).

Wiegman R and Wilson EA (2015) Introduction: Antinormativity's Queer Conventions. Differences 26: 1-25.

Wiegman R (2017) Sex and Negativity; or, What Queer Theory Has for You. Cultural Critique 95: 219-243.

Zanghellini A (2009) Queer, Antinormativity, Counter-Normativity and Abjection. Griffith Law Review 18: 1-16. 